\title{
Amino Acid Profile of Protein from Pelvic Limb Long Bones of Broiler Chickens
}

\author{
Eva Straková ${ }^{1}$, Pavel Suchý ${ }^{1}$, Ivan Herzig ${ }^{1}$, Ladislav Steinhauser ${ }^{1}$, Vlasta Šerman ${ }^{2}$, \\ Nora $\mathrm{Mas}^{2}$ \\ ${ }^{1}$ Faculty of Veterinary Hygiene and Ecology University of Veterinary and Pharmaceutical Sciences, \\ Brno, Czech Republic \\ ${ }^{2}$ Faculty of Veterinary Medicine, University of Zagreb, Croatia \\ Received February 3, 2009 \\ Accepted April 6, 2009
}

\begin{abstract}
The objective of the study was to determine the amino acid profile in protein from long bones of the pelvic limb (femur, tibiotarsus) in ROSS 308 hybrid broiler chickens, and to examine whether it is sex-dependent. The study material was obtained from 120 Ross 308 broiler chickens ( 60 males and 60 females) at the end of the fattening (40 days of age). The average weight of birds was $2694 \pm 32.6 \mathrm{~g}$ for cockerels and $2345 \pm 23.9 \mathrm{~g}$ for pullets. The study birds did not show any clinical signs of leg diseases. The long bones of the right pelvic limbs (femur and tibiotarsus) were collected after bird slaughter and after removal of soft tissues, they were used for laboratory analyses. The crude protein content and the amino acid (AA) composition were determined and the obtained values were recalculated to $100 \%$ dry matter. The chemical score (CS) and the essential amino acid index (EAAI) were calculated for each AA. As a standard, the hen egg ovalbumin was used. The crude protein content in $100 \%$ dry matter shows that the content of crude protein was significantly higher $(P \leq 0.01)$ in the femur $(405.3 \pm 17.21 \mathrm{~g} / \mathrm{kg})$ compared to the tibiotarsus $(393.5 \pm 12.68 \mathrm{~g} / \mathrm{kg})$. The same trends were found with regard to sex. Both males and females had significantly $(P \leq 0.01)$ higher crude protein content in the femur $(406.6 \pm 19.34 \mathrm{~g} / \mathrm{kg}$ and $404.1 \pm 15.09 \mathrm{~g} / \mathrm{kg}$, respectively) than in the tibiotarsus $(395.0 \pm 12.16 \mathrm{~g} / \mathrm{kg}$ and $392.1 \pm 13.21 \mathrm{~g} / \mathrm{kg}$, respectively). Both bones showed the highest contents of Gly, Glu and Pro, and the lowest contents of Met, Tyr and His. The same trends were found with regard to chicken sex. Collagenous protein has lower contents of most AA in comparison to the standard protein - ovalbumin; especially contents of Ser, Val, Met, Ileu and Phe are substantially lower. On the other hand, collagenous protein had higher contents of Gly, Pro, His and Arg. The collagenous protein EAAI for the femur and the tibiotarsus was $59.0 \%$ and $57.4 \%$, respectively. The knowledge of amino acid composition in protein from long bones of the pelvic limb in broiler chickens is important because it can help us understand the origin of bone disorders.
\end{abstract}

Femur, tibiotarsus, crude protein, chemical score, essentials amino acid index

Bones are predominantly composed of the inorganic mineral hydroxyapatite $\left(\mathrm{Ca}_{10}\left(\mathrm{PO}_{4}\right)_{6} \mathrm{OH}_{2}\right)$. Approximately $30 \%$ of bone tissue consists of organic compounds of which $90-95 \%$ is represented by collagen. The remaining portion is made up of proteins, particularly osteocalcin which is one of the most widespread non-collagen proteins, representing up to $3 \%$ of total protein in bones. Collagen is a water-insoluble protein which forms the main part of connective tissue. It represents $30 \%$ of total body protein (Mosby 2009). It is a fibrous protein that ensures bone strength and flexibility. It is an important component of a number of other tissues including the skin and tendons. Collagen molecules consist of linear, unbranched sequences of approximately 20 amino acids. The molecule's structure is stabilized by hydrogen bonding. Of all AAs, glycine is the most frequent amino acid contained in collagen. Collagen is also rich in proline and hydroxyproline, which are present at unusually high contents (Steinhauser 2000). The results reported by Rath et al. (1999), Skinner and Waldroup (1995) have shown that a number of biochemical, biomechanical, and physical properties of the tibia in broiler chickens are sex-dependent.

Address for correspondence:

Prof. Ing. Eva Straková, Ph.D.

University of Veterinary and Pharmaceutical Sciences, Brno

Faculty of Veterinary Hygiene and Ecology

Department of Nutrition, Animal Husbandry and Animal Hygiene

Palackého 1/3, 61242 Brno

Czech Republic

Phone: +420541562672

Fax: +420 541562675

e-mail: strakovae $(a$ vfu.cz

http://www.vfu.cz/acta-vet/actavet.htm 
For example, the content of collagen is higher in males than in females whereas the opposite trend was observed for ash, $\mathrm{Ca}, \mathrm{P}$, and collagenase-resistant matrix. Research into the properties of long bones from the pelvic limb, including the profile of AAs in bone protein, is important as it helps to explain the origins of bone disorders in broiler chickens that cause serious problems in broiler production, welfare, and breeding.

The main aim of the present work was to determine the amino acid profile in protein isolated from long bones of the pelvic limb (femur, tibiotarsus) in ROSS 308 hybrid broiler chickens, and to examine whether it is sex-dependent.

The study of long bones of the pelvic limb including the amino acid profile of bone proteins is important with regard to the occurrence of bone disorders in broiler chickens which impair broiler performance and affect the welfare of broilers.

\section{Materials and Methods}

Broiler chickens were reared in the accredited enclosures of the Department of Nutrition, Animal Husbandry and Animal Hygiene, Faculty of Veterinary Hygiene and Ecology, University of Veterinary and Pharmaceutical

Table 1. The contents of nitrogen substances in bones (the femur and the tibiotarsus) per $100 \%$ of dry matter $(\mathrm{g} / \mathrm{kg})$. The amino acids profile of bones (the femur and the tibiotarsus) per $100 \%$ of dry matter (expressed as $\mathrm{g}$ of $\mathrm{AA} / \mathrm{kg}$ of bone tissue); $(\mathrm{x} \pm \mathrm{SD})$

\begin{tabular}{|c|c|c|}
\hline $\mathrm{CP}$ & Femur & Tibiotarsus \\
\hline $\begin{array}{l}(\delta+q) \\
n=120\end{array}$ & $405.34 \pm 17.21^{* *}$ & $393.52 \pm 12.68$ \\
\hline 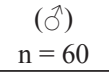 & $406.56 \pm 19.34^{* *}$ & $394.97 \pm 12.15$ \\
\hline $\begin{array}{c}(q) \\
\mathrm{n}=60\end{array}$ & $404.12 \pm 15.08^{* *}$ & $392.07 \pm 13.20$ \\
\hline AAs & Femur & Tibiotarsus \\
\hline \multicolumn{3}{|c|}{$(ठ+\phi) n=120$} \\
\hline Asp & $26.99 \pm 1.85^{* *}$ & $25.98 \pm 1.45$ \\
\hline Thr & $11.22 \pm 1.02^{* *}$ & $10.65 \pm 0.68$ \\
\hline Ser & $11.83 \pm 0.87^{* *}$ & $11.37 \pm 0.69$ \\
\hline Glu & $37.93 \pm 2.09^{* *}$ & $36.70 \pm 1.67$ \\
\hline Pro & $32.37 \pm 1.19^{* *}$ & $31.73 \pm 1.38$ \\
\hline Gly & $49.63 \pm 2.23$ & $49.20 \pm 2.01$ \\
\hline Ala & $28.00 \pm 1.59^{*}$ & $27.52 \pm 1.29$ \\
\hline Val & $14.03 \pm 1.21^{* *}$ & $13.30 \pm 0.92$ \\
\hline Met & $3.88 \pm 1.48$ & $3.66 \pm 0.84$ \\
\hline Ileu & $9.94 \pm 0.89^{* *}$ & $9.38 \pm 0.60$ \\
\hline Leu & $21.83 \pm 1.83^{* *}$ & $20.63 \pm 1.32$ \\
\hline Tyr & $6.83 \pm 0.89$ & $6.92 \pm 1.00$ \\
\hline Phe & $12.89 \pm 1.01^{* *}$ & $12.19 \pm 0.83$ \\
\hline His & $9.59 \pm 0.97^{* *}$ & $8.82 \pm 0.58$ \\
\hline Lys & $19.69 \pm 1.54^{* *}$ & $18.84 \pm 1.21$ \\
\hline Arg & $24.80 \pm 2.23^{* *}$ & $24.80 \pm 1.16$ \\
\hline $\mathrm{CP}$ & 405.34 & 393.52 \\
\hline$\% \mathrm{AAs}$ & 79.30 & 79.03 \\
\hline
\end{tabular}

CP crude protein

AAs amino acids

$(P \leq 0.01) * *$

$(P \leq 0.05) *$
Sciences, Brno. Experimental material was collected from a total of 120 ROSS 308 hybrid broiler chickens (60 males, 60 females) aged 40 days, weighing $2694 \pm$ $32.6 \mathrm{~g}$ (males) and $2345 \pm 23.9 \mathrm{~g}$ (females), at the end of the fattening period. None of the individual animals included in this experiment showed clinical symptoms of any limb disease. Long bones of the right pelvic limb (the femur and the tibiotarsus) were collected from slaughtered animals and subjected to laboratory testing after removal of soft tissue.

The content of crude protein was determined using the Buchi analyser (manufactured by Centec automatika, s. r.o.). The amino acid profile was determined after acid hydrolysis using $6 \mathrm{~N} \mathrm{HCl}$ at $110^{\circ} \mathrm{C}$ for $24 \mathrm{~h}$ using the AAA 400 automatic amino acid analyzer (manufactured by INGOS a.s. Prague, Czech Republic) on the basis of a colour reaction between a particular amino acid and ninhydrin (oxidizing agent). Dry matter was also determined (AOAC, 2001), and findings were recalculated to $100 \%$ of dry matter.

The chemical score (CS) was calculated for each amino acid according to the following formula: $\mathrm{CS}=\mathrm{Ax} /$ As, where in Ax is the content of an amino acid in the investigated protein (\%) and As is the content of an amino acid in the standard protein. Chicken egg ovalbumin was used as standard. The Essential Amino Acid Index (EAAI) is a geometrical average of CS values (Davídek et al. 1983; Písaříková et al. 2005).

Statistical characteristics were obtained using ANOVA, followed by a multiple comparison using Tukey-HSD test to find the pairs of groups with significant differences.

\section{Results and Discussion}

The content of N-substances was significantly higher $(P \leq 0.01)$ in the femur $(405.3 \pm 17.21 \mathrm{~g} / \mathrm{kg})$ compared to the tibiotarsus $(393.5 \pm 12.68 \mathrm{~g} / \mathrm{kg})$. The same trends were also found in relation to sex. The content of $\mathrm{N}$-substances in male and female chickens was significantly higher $(P \leq 0.01)$ in the femur $(406.6 \pm 19.34 \mathrm{~g} / \mathrm{kg}$ or $404.1 \pm 15.09 \mathrm{~g} / \mathrm{kg}$, respectively) than 
Table 2. The amino acids profile of bones (the femur and the tibiotarsus) per $100 \%$ of dry matter (expressed as $\mathrm{g}$ of $\mathrm{AA} / \mathrm{kg}$ of bone tissue) in male and female chickens $(x \pm S D)$

\begin{tabular}{|c|c|c|}
\hline $\begin{array}{c}\text { AAs }(ð) \\
\mathrm{n}=60\end{array}$ & Femur & Tibiotarsus \\
\hline Asp & $27.44 \pm 2.15^{*}$ & $26.57 \pm 1.71$ \\
\hline Thr & $11.14 \pm 1.03 *$ & $10.80 \pm 0.73$ \\
\hline Ser & $11.85 \pm 0.96$ & $11.56 \pm 0.79$ \\
\hline Glu & $38.03 \pm 2.21 * *$ & $36.98 \pm 1.57$ \\
\hline Pro & $32.51 \pm 1.29 *$ & $31.78 \pm 1.72$ \\
\hline Gly & $49.76 \pm 2.21$ & $49.42 \pm 1.93$ \\
\hline Ala & $28.41 \pm 1.61 *$ & $27.85 \pm 1.28$ \\
\hline Val & $14.08 \pm 1.25$ & $13.76 \pm 1.00$ \\
\hline Met & $3.71 \pm 2.24 *$ & $3.63 \pm 0.87$ \\
\hline Ileu & $9.88 \pm 0.88^{* *}$ & $9.48 \pm 0.65$ \\
\hline Leu & $21.61 \pm 1.99 *$ & $20.81 \pm 1.40$ \\
\hline Tyr & $6.40 \pm 0.82 * *$ & $7.01 \pm 1.03$ \\
\hline Phe & $12.86 \pm 1.08^{*}$ & $12.49 \pm 0.85$ \\
\hline His & $9.42 \pm 1.02 * *$ & $8.85 \pm 0.45$ \\
\hline Lys & $19.45 \pm 1.60$ & $19.05 \pm 1.32$ \\
\hline Arg & $24.61 \pm 1.55$ & $24.30 \pm 1.26$ \\
\hline CP & 406.56 & 394.97 \\
\hline$\%$ AAs & 78.99 & 79.59 \\
\hline & & \\
\hline
\end{tabular}

\begin{tabular}{|c|c|c|}
\hline $\begin{array}{c}\text { AAs (o) } \\
n=60\end{array}$ & Femur & Tibiotarsus \\
\hline
\end{tabular}

\begin{tabular}{|l|l|l|}
\hline Asp & $26.55 \pm 1.55^{* *}$ & $25.37 \pm 1.20$ \\
\hline Thr & $11.30 \pm 1.01 * *$ & $10.50 \pm 0.64$ \\
\hline Ser & $11.81 \pm 0.78^{* *}$ & $11.18 \pm 0.59$ \\
\hline Glu & $37.83 \pm 1.97 * *$ & $36.41 \pm 1.78$ \\
\hline
\end{tabular}

\begin{tabular}{|l|l|l|}
\hline Pro & $32.24 \pm 1.09 * *$ & $31.68 \pm 1.04$ \\
\hline Gly & $49.50 \pm 2.25$ & $48.98 \pm 2.09$ \\
\hline Ala & $28.31 \pm 1.57 * *$ & $27.19 \pm 1.31$ \\
\hline Val & $13.99 \pm 1.16 * *$ & $12.83 \pm 0.84$ \\
\hline
\end{tabular}

\begin{tabular}{|c|c|r|}
\hline Met & $4.05 \pm 0.72 *$ & $3.69 \pm 0.80$ \\
\hline Ileu & $10.00 \pm 0.89 * *$ & $9.28 \pm 0.54$ \\
\hline Leu & $22.06 \pm 1.67 * *$ & $20.45 \pm 1.25$ \\
\hline Tyr & $7.27 \pm 0.97 *$ & $6.83 \pm 0.97$ \\
\hline Phe & $12.93 \pm 0.94 * *$ & $11.90 \pm 0.80$ \\
\hline His & $9.76 \pm 0.92 * *$ & $8.79 \pm 0.72$ \\
\hline Lys & $19.94 \pm 1.48 * *$ & $18.64 \pm 1.11$ \\
\hline Arg & $24.99 \pm 2.90 * *$ & $23.89 \pm 1.06$ \\
\hline CP & 404.12 & 392.07 \\
\hline$\%$ AAs & 79.81 & 78.46 \\
\hline
\end{tabular}
$(P \leq 0.01) * *$ $(P \leq 0.05) *$

matter and connective tissue proteins accounted for $72.3-81.1 \%$

In comparison with the full-value standard protein (ovalbumin), protein isolated from long bones of the pelvic limb showed lower contents of most amino acids; the in the tibiotarsus $(395.0 \pm 12.16 \mathrm{~g} / \mathrm{kg}$ or $392.1 \pm 13.21 \mathrm{~g} / \mathrm{kg}$, respectively). Rath et al. (1999) have reported higher content of collagen in the tibia in males compared to females. Although indirectly, this is also confirmed by our results, which show that the content of $\mathrm{N}$-substances in both bones in males were higher than those in females (Table 1), and since the content of collagen in bone protein is high $(80-95 \%)$, this finding applies particularly to this protein. It also follows from the profile of nitrogen substances in the tibiotarsus compared to the femur that the tibiotarsus is more suitable for studying mineral metabolism as it gives higher ash content compared to the femur (Suchý et al. 2009).

The amino acid profile in protein isolated from the examined bones (expressed as $g$ of AAs per $\mathrm{kg}$ of bone tissue) is provided in Table 1. Except for Gly, Met and Tyr, the contents of other AAs were significantly higher $(P \leq$ $0.01 ; P \leq 0.05)$ in the femur compared to the tibiotarsus. In both bones, Gly, Glu and Pro were the most abundant amino acids, whereas amino acids in both bones. The same trends were found in relation to sex. Both males and females showed higher contents of amino acids in the femur compared to the tibiotarsus (Tables 2 and 3). Significant differences were of higher significance in females (a nonsignificant difference was only found for Gly) whereas in males the differences for six AAs (Ser, Gly, Val, Met, Lys, Arg) failed to be significant. Tyr was the only amino acid to show a significant increase in the tibiotarsus in males.

The results of the amino acid profile in the protein component of long bones of the pelvic limb (femur and tibiotarsus) in ROSS 308 hybrid broiler chickens are completely new; no such data have been published in the available literature. In their paper examining the quality of protein in bones from young bulls, Zarkadas et al. (1995) reported that the content of total protein of demineralised bone powder varied between $78-80 \%$ in dry Met, Tyr and His were the least abundant 
Table 3. Mean contents of amino acids in protein from long bones of the pelvic limb in broiler chickens (g/16 g

\begin{tabular}{|c|c|c|c|c|c|c|}
\hline & Femur & Tibiotarsus & Femur & Tibiotarsus & Femur & Tibiotarsus \\
\hline $\mathrm{n}$ & 120 & 120 & 60 & 60 & 60 & 60 \\
\hline Sex & $\hat{\sigma}+q$ & $\hat{\sigma}+q$ & $\hat{\sigma}$ & $\delta$ & q & 우 \\
\hline Asp & 6.66 & 6.60 & 6.75 & 6.72 & 6.57 & 6.47 \\
\hline Thr & 2.77 & 2.71 & 2.74 & 2.73 & 2.80 & 2.68 \\
\hline Ser & 2.92 & 2.89 & 2.91 & 2.93 & 2.92 & 2.85 \\
\hline Glu & 9.36 & 9.33 & 9.35 & 9.36 & 9.36 & 9.29 \\
\hline Pro & 7.99 & 8.06 & 8.0 & 8.05 & 7.98 & 8.08 \\
\hline Gly & 12.24 & 12.50 & 12.24 & 12.51 & 12.25 & 12.49 \\
\hline Ala & 6.91 & 6.99 & 6.99 & 7.05 & 7.00 & 6.93 \\
\hline Val & 3.46 & 3.38 & 3.46 & 3.48 & 3.46 & 3.27 \\
\hline Met & 0.96 & 0.93 & 0.91 & 0.92 & 1.00 & 0.94 \\
\hline Ileu & 2.45 & 2.38 & 2.43 & 2.40 & 2.47 & 2.37 \\
\hline Leu & 5.39 & 5.24 & 5.32 & 5.27 & 5.46 & 5.22 \\
\hline Tyr & 1.68 & 1.76 & 1.57 & 1.77 & 1.80 & 1.74 \\
\hline Phe & 3.18 & 3.10 & 3.16 & 3.16 & 3.20 & 3.04 \\
\hline His & 2.37 & 2.24 & 2.32 & 2.24 & 2.42 & 2.24 \\
\hline Lys & 4.86 & 4.79 & 4.78 & 4.82 & 4.93 & 4.75 \\
\hline Arg & 6.12 & 6.12 & 6.05 & 6.15 & 6.18 & 6.09 \\
\hline Sum & 79.31 & 79.02 & 78.98 & 79.56 & 79.80 & 78.45 \\
\hline $\mathrm{CP}$ & 405.34 & 393.52 & 406.56 & 394.97 & 404.12 & 392.07 \\
\hline $\mathrm{N}$ & 64.85 & 62.96 & 65.05 & 63.19 & 64.66 & 62.73 \\
\hline
\end{tabular}

CP: crude protein

$\mathrm{N}$ : nitrogen

contents were particularly decreased for the following amino acids: Gly (39\%), Pro (46\%), $\operatorname{Arg}(64 \%)$, and His (78\%), whereas ovalbumin showed relatively high contents of Met (434\%), Ser (313\%), Ileu (261\%), Val (208\%), and Phe (175\%) (Fig. 1).

The biological value of protein in the femur and tibiotarsus is provided in Tables 4 and 5. High values of CSs were found for Gly, Pro, Arg, and His. Low contents were found for Met, Ser, Ileu, and Val. As a result, these amino acids can be considered as limiting amino acids. The biological value for collagenous protein expressed as EAAI is very low, being very similar for both bones, namely $59.0 \%$ for the femur and $57.4 \%$ for the tibiotarsus. The above-mentioned findings, such as the contents of AAs in collagenous protein, show that the collagen's protein value is primarily limited by the content of methionine. This finding corresponds closely with the results reported by Klemesrut et al. (1997), who identified methionine as a limiting amino acid in meat-and-bone meals and a meal-like by-product made of poultry. On the other hand, Wang et al. (1997) reported a different sequence of limiting amino acids in a meat-and-bone meal, with Trp and sulphur-containing amino acids in the first two places followed by Thr, Ileu and Phe+Tyr, Met, Lys, Val, and His. Shirley and Parsons (2001), who studied the effect of ash content on the AA profile in a meat-and-bone meal, found that with an increasing portion of ash, amino acids such as Ala, Pro, Gly, and Arg showed highest relative contents $(\%)$, where the highest increase was observed for Pro and Gly, which closely corresponds with our findings.

Our study has provided completely new data on the physiological amino acid contents in protein from long bones (femur, tibiotarsus) and on the sex-dependent differences in broiler chickens. 


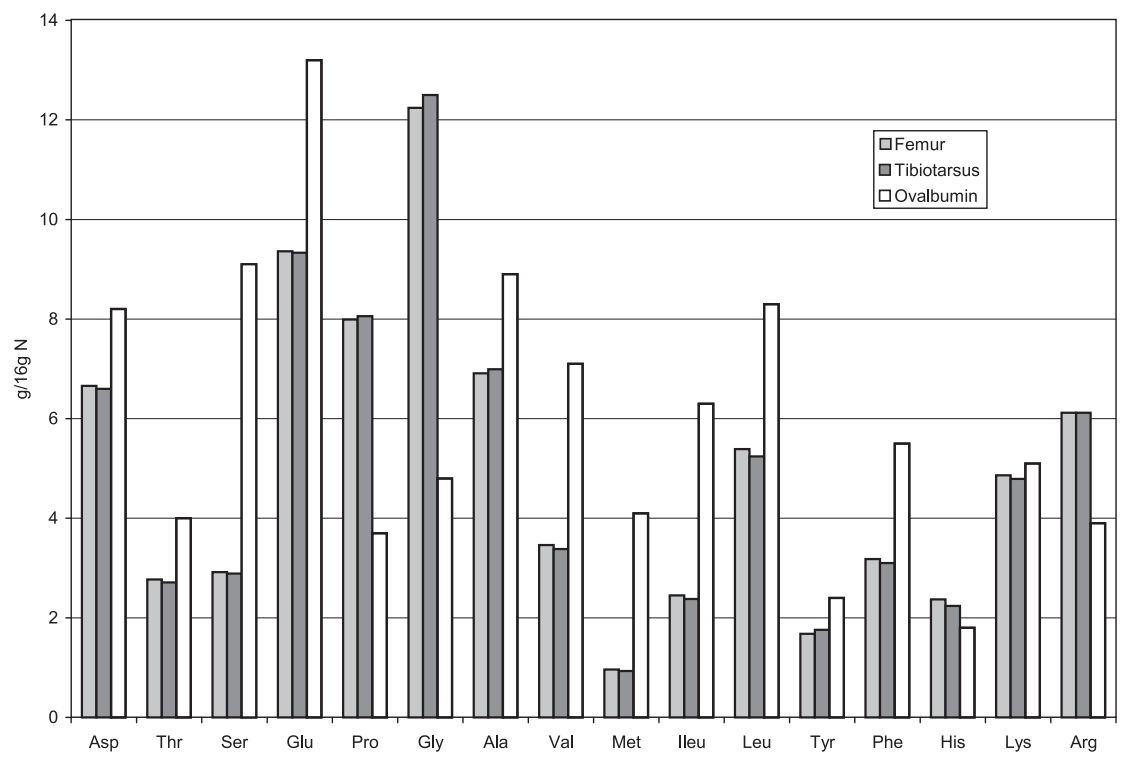

Fig. 1. The amino acid profile of protein from long bones of the pelvic limb in chickens compared to the ovalbumin standard (femur, tibiotarsus, ovalbumin)

Table 4. The contents of amino acids (as $\mathrm{g} / 16 \mathrm{~g} \mathrm{~N}$ ) and chemical scores (CS)

\begin{tabular}{|l|c|c|c|c|c|}
\hline AAs & Ovalbumin & Femur & CS \% & Tibiotarsus & CS \% \\
\hline $\mathrm{n}$ & & 120 & & 120 & \\
\hline Asp & 8.2 & 6.66 & 81.2 & 6.60 & 80.5 \\
\hline Thr & 4.0 & 2.77 & 69.2 & 2.71 & 67.8 \\
\hline Ser & 9.1 & 2.92 & 32.1 & 2.89 & 31.8 \\
\hline Glu & 13.2 & 9.36 & 70.9 & 9.33 & 70.7 \\
\hline Pro & 3.7 & 7.99 & 215.9 & 8.06 & 217.8 \\
\hline Gly & 4.8 & 12.24 & 255.0 & 12.50 & 260.4 \\
\hline Ala & 8.9 & 6.91 & 77.6 & 6.99 & 78.5 \\
\hline Val & 7.1 & 3.46 & 48.7 & 3.38 & 47.6 \\
\hline Met & 4.1 & 0.96 & 23.4 & 0.93 & 22.7 \\
\hline Ileu & 6.3 & 2.45 & 38.9 & 2.38 & 37.8 \\
\hline Leu & 8.3 & 5.39 & 64.9 & 5.24 & 63.1 \\
\hline Tyr & 2.4 & 1.68 & 70.0 & 1.76 & 73.3 \\
\hline Phe & 5.5 & 3.18 & 57.8 & 3.10 & 56.4 \\
\hline His & 1.8 & 2.37 & 131.7 & 2.24 & 124.4 \\
\hline Lys & 5.1 & 4.86 & 95.3 & 4.79 & 93.9 \\
\hline Arg & 3.9 & 6.12 & 156.9 & 6.12 & 156.9 \\
\hline
\end{tabular}

\section{Aminokyselinové složení proteinu dlouhých kostí pánevní končetiny brojlerových kuřat}

Experimentální materiál byl získán od 120 brojlerových kuřat (60 kohoutků, 60 slepiček) hybrida ROSS 308, na konci výkrmu ve věku 40 dnů, při průměrné hmotnosti kohoutků $2694 \pm 32,6 \mathrm{~g}$ a $2345 \pm 23,9 \mathrm{~g}$ u slepiček. U sledovaných jedinců neby- 
Table 5. Chemical scores (CS \%) and Essential Amino Acid Index (EAAI \%) in protein from the femur and tibiotarsus

\begin{tabular}{|l|c|c|}
\hline Amino acids & CS \% - femur & CS \% - tibiotarsus \\
\hline His & 131.7 & 124.4 \\
\hline Ile & 38.9 & 37.8 \\
\hline Leu & 64.9 & 63.1 \\
\hline Lys & 95.3 & 93.9 \\
\hline Met + Cys & 23.4 & 22.7 \\
\hline Thr & 69.2 & 67.8 \\
\hline Val & 48.7 & 47.6 \\
\hline EAAI & 59.0 & 57.4 \\
\hline
\end{tabular}
aminokyseliny byla vypočítána hodnota chemical score (CS) a essentials amino acid index (EAAI). Jako standard byl použit ovalbumin slepičího vejce. Obsah dusíkatých látek ve $100 \%$ sušině dokládá, že hladina N-látek byla statisticky významně vyšší $(P \leq 0.01) \quad$ u kosti stehenní $(405.3 \pm 17.21 \mathrm{~g} / \mathrm{kg})$ ve srovnání s kostí holenní $(393.5 \pm 12.68 \mathrm{~g} / \mathrm{kg})$. Stejné trendy byly zaznamenány i vzhledem $\mathrm{k}$ pohlaví kuřat. Jak u kohoutků, tak u slepiček byly hladiny $\mathrm{N}$ látek významně vyšší $(P \leq 0.01)$ u kosti stehenní $(406.6 \pm 19.34 \mathrm{~g} / \mathrm{kg}$, resp. $404.1 \pm 15.09 \mathrm{~g} / \mathrm{kg})$ než u kosti holenní ( $395.0 \pm 12.16 \mathrm{~g} / \mathrm{kg}$, resp. $392.1 \pm 13.21 \mathrm{~g} / \mathrm{kg}$ ). V obou kostech měly nejvyšší zastoupení AA Gly, Glu a Pro, nejnižší hladiny byly nalezeny u Met, Tyr a His. Stejné trendy byly zaznamenány vzhledem k pohlaví kuřat. V porovnání se standardním proteinem - ovalbuminem má kolagenní protein nižší hladiny většiny AA. Výrazně nižší jsou u ovalbuminu hladiny Gly (39\%), Pro (46 \%), Arg (64\%) a His (78 \%), naopak vyšší hodnoty ovalbuminu jsou u Met (434\%), Ser (314 \%), Ileu $(261 \%)$, Val $(208 \%)$ a Phe $(175 \%)$. EAAI proteinu pro kost stehenní byl 59,0\%, pro kost holenní $57,4 \%$. Cílem práce bylo stanovit aminokyselinové složení proteinu dlouhých kostí pánevní končetiny (kost stehenní a holenní) brojlerových kuřat hybrida ROSS 308, s prrihlédnutím na možný vliv pohlaví kuřat. Studium vlastností dlouhých kostí pánevní končetiny, včetně zastoupení aminokyselin v proteinu kostí, je důležité z hlediska vzniku poruch kostí u brojlerových kuřat, nebot' jsou příčinou významných problémů produkce, ale i welfare jejich chovu.

\section{Acknowledgement}

Financial support from the Ministry of Education, Youth, and Sports of the Czech Republic (Grant No MSMT $6215712402)$ is gratefully acknowledged.

\section{References}

AOAC 2001: International Official Methods of Analysis. $17^{\text {th }}$ ed. AOAC Int., Arlington, VA Davídek J, Janíček G, Pokorný J 1983: Foodstuffs Chemistry. SNTL, Praha, 632 p.

Klemesrud MJ, Klopfenstein TJ, Lewis AJ, Shain DH, Herold DV 1997: Limiting amino acids in meat and bone and poultry by-product meals. J Anim Sci 75: 3294-3300

Mosby's Medical Dictionary, 8th edition. (2009). Retrieved October 82009 from http://medical-dictionary. thefreedictionary.com/collagen

Oviedo-Rondon EO, Ferket PR, Havenstein GB 2006: Understanding long bone development in broilers and turkeys. Avian Poult Biol Rev 17: 77-88

Písař́k ová B, Kráčmar S, Herzig I 2005: Amino acid contents and biological value of protein in various amaranth species. Czech J Anim Sci 50: 169-174

Rath NC, Balog JM, Huff WE, Huff GR, Kulkarni GB, Tierce JF 1999: Comparative differences in the composition and biomechanical properties of tibia of seven- and seventy-two-week-old male and female broiler breeder chickens. Poult Sci 78: 1232-1239

Shirley RB, Parsons CM 2001: Effect of ash content on protein quality of meat and bone meal. Poult Sci 80: 626-632

Skinner JT, Waldroup PW 1995: Allometric bone development in floor-reared broilers. J Appl Poult Res 4: 265-270 
Suchý P, Straková E, Herzig I, Steinhauser L, Kralik G, Zapletal D 2009: Chemical composition of bone tissue in broiler chickens intended for slaughter. Czech J Anim Sci 54: 324-330

Steinhauser L 2000: Meat production. VPL Tišnov: 464 p.

Straková E, Suchý P, Večerek V, Máchal L 2002: The variation in amino acid levels in the blood plasma of breeding roosters during sexual maturation. Arch Tierz 45: 279-285

Wang XC, Castanon F, Pardone CM 1997: Order of amino acid limitation in meat and bone meal. Poult Sci 76: $54-58$

Zarkadas CG, Yu ZR, Zarkadas GC, Mineroamadior A 1995: Assessment of the protein-quality of beefstock bone isolates for use as an ingredient in meat and poultry products. J Agric Food Chem 43: 77-83 
